\title{
Student Opinion Scale Related to Moodle LMS in an Online Learning Environment: Validity and Reliability Study
}

\author{
https://doi.org/10.3991/ijim.v12i4.9205 \\ Ezgi Pelin Yildiz( ${ }^{(凶)}$, Murat Tezer, Hüseyin Uzunboylu \\ Near East University, Nicosia, Cyprus \\ yildizezgipelin@gmail.com
}

\begin{abstract}
The purpose of this study is to develop a Student Opinion Scale Related to Moodle LMS (Learning Management System) in an Educational Online Learning Environment. For this purpose, a scale form consisting of 34 items was created and then administered to a total of 280 first-year students from various departments of the Near East University Health Services Vocational High School. Rotated principal component analysis was used to obtain information on the validity of the scale. The data was processed using the SPSS 23.0 software package and the results are given as arithmetic average and standard deviation. In this context, it has been determined that the related items for the scale are collected in 6 dimensions, which have been categorized by the researchers as: Proficiency and Motivation"; "Content and Feedback"; "Usability"; "Effectiveness"; "Educational Features" and "Communication". Additionally, the reliability coefficient calculated by Cronbach's alpha for the developed scale is .94. Based on the overall results of the study, student opinion has been found to be positive related to Moodle LMS in an Educational Online Learning Environment.
\end{abstract}

Keywords-Moodle, Learning Management System, Scale Development, Validity, Reliability

\section{Introduction}

As a result of software packages including Learning Management System, Learning Content Management System, Course Management Information System, Virtual Learning Environment, it is no longer necessary for students and educators to be in the same physical environment (Uzunboylu et al., 2006). Today, programs such as Moodle, Blackboard, Sakai, Docebo, and ATutor, are now widely used in schools and universities, particularly in the area of higher education, and provide strong support for teaching (Caputi \& Garrido, 2015).

Based on the literature related to the field, Aydın and Biroğul (2008) provided information about open source code learning management systems used in the elearning process. Benchmarks for existing software have been implemented and, as a result, the Moodle learning management system has become the most prominent 
software. One of the most widely used open source learning management systems (LMS) is Moodle, according to Önal et al. (2006). Moodle is a learning management system that can be easily used by all users (student, teachers/teaching staff) as an online lesson and course management system that can respond to the majority of needs related to online teaching. The software can run under MySQL and PostgreSQL database systems and in any environment that supports the PHP language (Linux, Windows, Mac OS X, etc.). It is also available in 235 countries and supports 82 different languages. In addition to this, it is accessible to thousands of students and there are many sample courses. Moodle offers functionality in almost all network learning platforms such as assignments, exams, forums, discussion boards, newsletters, and content management. Moodle, a prestigious open source course management system, is now widely preferred by educator's schools, educational institutions and even commercial institutions (Seferoğlu, 2016). Teachers and/or lecturers can use the Moodle platform to prepare web-based courses with rich content that can be integrated into educational systems. At the same time, by categorizing lessons, they can also make use of the tools that create group activities such as materials, exams, tests, scales and projects in these categories (Şimsek, 2015). One of the greatest advantages of Moodle when viewed in general terms is that it is open source and only requires a single entry for users. Thus, users are only accustomed to a single user interface. Another advantage of Moodle is that it is user-friendly. Nowadays, particularly in online courses, it is easy to use the Moodle platform by simply registering and then adding account information. In a broader context, platform users can easily access relevant online courses from anywhere in the world at any given time. In this sense, the independence of time and place is accompanied by the autonomous learning of learners as well as learning environments that support cooperation. Besides support for course design and course management, Moodle also offers enriched multimedia learning resources, communicative and collaborative learning-based activities (forum, chat, wiki, etc.), communicative contact and guidance with the tutor, as well as controlled learning through feedback, evaluation, tracking statistics.

Moodle is an e-learning platform that can be successfully used today in private or public institutions in the education system. Additionally, the platform is often employed in educational curricula at universities for various purposes. Distance learning, e-learning, flipped classroom model, and mixed learning are some of the aspects that Moodle can facilitate (Oproiu, 2014).

A Modular Object-Oriented Dynamic Learning Environment (Moodle) is an opensource that provides the ability to create, deploy and manage e-learning websites and applications. Modular Object-Oriented Dynamic Learning Environments are a type of learning management system (LMS) or online learning system (OLS). They were initially developed by educators and are now maintained by Moodle Community and Moodle HQ.

In theory, Moodle is based on social constructivist theory (Downes, 2006; Şahinoğlu, 2012). The theory was conceived by Vygotsky. Learning and cognitive development is a social and collaborative activity in which the child learns in meaningful contexts and at the same time cannot be considered apart from the real world developments; thus, the in-school experiences are related to the child's non-school experi- 
Paper-Student Opinion Scale Related to Moodle LMS in an Online Learning Environment: Validity ...

ences (Senemoğlu, 2011). Moodle supports an interactive learning style based on the social constructivist education concept (Rice, 2006; Şahinoğlu, 2012).

For most students, mathematics has been composed of senseless and complex formula sequences, methods or rules and memorisation (Ersoy, 1997). One of the main reasons of these negative attitudes about mathematics is the insufficiency or insufficient use of learning-teaching methods, tecniques that has been used to earn skills (Mutluay, 2004). Apart from all these, it is a possibility to have benefit from technology in order to improve students' attiutudes towords methematics. In this context, learning management systems are platforms that could be used in the scope of defined objectives of various educational stages. Many learning management systems have been ensued, when the literature is examined. Atutor, Dokeos, Sakai, Olat are some of these. And many of these platforms, such as Moodle, Sakai, Docebo, Atutor, Ilias, LRN, etc., are increasingly being used in schools and universities as a powerful support and improvement for teaching activities (Caputi and Garrido, 2015).

Here are a few benefits of Moodle that make it the most popular LMS:

\subsection{Open Source}

Moodle is an open source platform, which means that its source code is accessible to all. It is distributed under the General Public License. In simple terms, users and administrators can freely run, share, and alter it to meet their particular commercial or non-commercial needs.

\subsection{Cost-effective}

No license fee is required to have the Moodle Learning Management System. Only development and maintenance costs have to be paid.

\subsection{Simple Interface}

Moodle is a user-friendly platform. The reason for this is the simple interface. The interface is based on HTML 5 and can be accessed on any mobile device.

\subsection{Easy to Customize}

Software platforms such as an LMS need customization to fit your organization's requirements. You need your company name, logo, and your brand colors to make it look as your training management platform rather than a random website. Doing this with Moodle is quite easy. Instructors and students can sign up, login, and receive a password if it is forgotten. Administrator is assigned with the user management authority where he can add/edit/update the user details, assign roles (can make a user as a co-administrator), and delete a user (Ippakayala \& El-Ocla, 2017). 
Paper-Student Opinion Scale Related to Moodle LMS in an Online Learning Environment: Validity ...

\subsection{Offline Access}

For developing countries, internet bandwidth can be a major issue while delivering online training. After all Moodle employees can be allowed to download and access their own devices from their device.

\section{The aim of study}

The purpose of this study is to develop a Student Opinion Scale Related to Moodle LMS (Learning Management System) in an Online Learning Environment. The scale is also a form of evaluation of the environment. The following sub-purpose has been established in order to achieve the stated goal:

What are the general opinions of students who use Moodle LMS in all dimensions?

\subsection{The importance of this study}

It is believed that for future investigations, the relevant scale may provide supportive evidence of the validity of the structure for different working groups. In addition to this, it is thought that for future research, the related scale can provide supportive evidence on the validity of construction on different working groups.

\section{$3 \quad$ Method}

This study is a scale development study. Scale development is the systematic process of creating and testing a questionnaire, survey, or rating scale items and response options (Morgado et al., 2017). For this purpose, an advanced literature search was conducted to achieve this goal and the theoretical framework of the scale was determined. The information on the study group as well as the development process of the scale and the follow-up actions are given below:

\subsection{Study Group}

Within this scope, the study group of the research consisted of 280 first year students who were studying in various department of the Near East University Health Services Vocational High School. Of the 280 students, 160 are male and 120 are female. Their age is between 17 and 26. The reason for the preference of the study group in the study is that Basic Mathematics course is a compulsory course for all first-year students studying at the Health Services Vocational School and students are required to have preliminary knowledge of mathematics in order to acquire basic skills in the field of health. It is also evident that many concepts in the field of health, including human physiology, can be explained with mathematics. 


\section{$4 \quad$ Findings}

\subsection{Develop of Scale}

In order to develop the Student Opinion Scale related to the Moodle DYBS with an Educational Online Learning Environment, a detailed literature search was performed. A pool that consists of 34 items based on the theoretical foundations for the scale was established as the first step. The opinions of three field specialists, one assessment and evaluation specialist, one language specialist and one Psychological Counselling and Guidance specialist regarding the pool were collected.

Exploratory Factor Analysis (EFA) was performed to show the validity of the structure. Prior to EFA, the KMO and Bartlett Sphericity test values were measured. The factor loading and communality values that were collected after the EFA analysis were reported. Finally, the Cronbach's alpha for the internal consistency reliability value was used to assess the reliability of the scale.

According to the collected data, it has been revealed by the conducted analysis studies that the scale has a 6-factor structure with 34 items. The scale has a five-point Likert-type structure. Student responses were taken according to the following: $5=\mathrm{I}$ absolutely agree, 4 = I agree, $3=\mathrm{I}$ am neutral, 2 = I do not agree, $1=\mathrm{I}$ totally disagree.

\subsection{Data Analysis}

The 34-item scale was applied to a total of 280 first-year students from various departments of the Near East University Health Services Vocational School. In the scope of the validity and reliability studies of the scale, all analysis in the study were performed with the SPSS 23 package program and the significance level in the test was determined to be 0.05 .

\subsection{Validity of the scale}

In order to determine the validity of the scale, the appearance, content and structural validities were all verified. The opinions of three field specialists, one assessment and evaluation specialist, one language specialist and one Psychological Counselling and Guidance specialist were collected for the face and content validities.

For the construct validity, the EFA test was conducted. According to the results of the EFA test, the 34-item and 6-factor structure of the scale with an eigenvalue of greater than 1 explains $66.60 \%$ of the total variance. As this explained variance rate is higher than $30 \%$, it is considered to be sufficient for sciences (Büyüköztürk, 2013).

\subsection{Exploratory factor analysis and reliability}

In the study, the "oblique rotation" technique was preferred for the data set. The most frequently used oblique rotation techniques are varimax and quartimax. Both 
techniques aim to bring the load values of the items closer to 1.00 in one factor and to 0 in the other factors (Büyüköztürk, 2013). When the varimax rotation used in the study is examined, it can be said that quartimax is a general factor that meets the majority of the variance and varimax is a more appropriate choice when the multifactorial structure of the variable is concerned (Büyüköztürk, 2013).

In order to determine whether the data was suitable for factor analysis, the KaiserMeyer-Olkin (KMO) test was applied. As this value approaches 1, that means that the application of factor analysis on the data group is applicable. If the KMO value is lower than 0.60 , factor analysis cannot be applied on the data group. In order for the factor analysis to be suitable, a KMO value higher than 0.60 is very important in terms of validity and the significance of the Bartlett's test results (Büyüköztürk, 2013). The determination of the scale elements was based on having a minimum total variance after Varimax rotation analysis of 0.30 and shows that scale has one factor (if the item is under two different factors with a high factor load, the minimum difference must be 0.10 ). These values vary in the literature and usually values of 0.30 and 0.40 are accepted as limits (Tuan et al. 2000; Johnson \& McClure 2004; Tsai \& Liu 2005; Gürbüztürk \& Şad, 2010). In this study, the sampling adequacy factor of KMO was calculated to be 0.86 . According to numerous researchers, when the reliability factor gets close to 1, the reliability increases. According to Fraenkel and Wallen (2006), if the reliability number is lower than 0.60 , this indicates that the scale is too weak, if it is between 0.60 and 0.70 , the scale is within acceptable limits and if it is higher than 0.80 , the scale reliability is very good.

Resultantly, the total item correlations are between .323 and .737 for the 34 items. In addition to this, the results obtained after the validity and reliability studies confirmed that the developed scale has a consistent structure within itself.

Table 1. Results related with KMO and Bartlett's tests

\begin{tabular}{lll}
\hline $\begin{array}{l}\text { Kaiser-Meyer-Olkin Measure of } \\
\text { Sampling Adequacy }\end{array}$ & 0.800 \\
\hline Bartlett's Test of Sphericity & Approx. Chi-Square & 8180.976 \\
& $d f$ & 561 \\
& Sig. (P) & .000 \\
\end{tabular}

As can be seen in Table 1, the KMO value is 0.800 . An examination of the results of the Bartlett's test reveals that the result (X2 $=8180.976$, $\mathrm{df}=561, \mathrm{p} \backslash 0.000)$ is significant. This proves that the data is suitable for exploratory factor analysis. Fraenkel and Wallen (2006) determined that, when the reliability coefficient is lower than 60 it is weak, when it is between .60 and .70 , it is within inacceptable limitations and when it is over .80, it is good. Furthermore,, Bartlett test's Chi-Square value is 6494.643 and degree of freedom is 2016 and significant $(p=00.00, p<0.05)$. The $p$ value in the Bartlett test is $.000<0.05$. As a result, the data of $\mathrm{KMO}$ and Bartlett are shown to suitable for factor analysis. 


\subsection{Analysis of the construct validity of the scale}

Finally, in order to explain the scale that consists of 34 items, the processes of specifying the number of factors, factor variance and naming the factors were conducted.

Table 2. Total Factor Analysis Variance Results

\begin{tabular}{|c|c|c|c|c|c|c|c|}
\hline \multirow[t]{2}{*}{ Component } & \multicolumn{3}{|c|}{ Initial eigenvalues } & \multicolumn{3}{|c|}{$\begin{array}{l}\text { Extraction sums of squared } \\
\text { loadings }\end{array}$} & \multirow[t]{2}{*}{$\begin{array}{l}\text { Rotation sums of } \\
\text { squared loadings }\end{array}$} \\
\hline & Total & $\begin{array}{c}\% \text { of } \\
\text { variance }\end{array}$ & $\begin{array}{l}\text { Cumulative( } \\
\%)\end{array}$ & Total & $\begin{array}{c}\% \text { of } \\
\text { variance }\end{array}$ & $\begin{array}{l}\text { Cumulative } \\
\text { (\%) }\end{array}$ & \\
\hline 1 & 12.306 & 36.195 & 36.195 & 12.306 & 36.195 & 36.195 & 5.438 \\
\hline 2 & 3.827 & 11.254 & 47.450 & 3.827 & 11.254 & 47.450 & 4.975 \\
\hline 3 & 2.053 & 6.037 & 53.487 & 2.053 & 6.037 & 53.487 & 4.137 \\
\hline 4 & 1.649 & 4.851 & 58.338 & 1.649 & 4.851 & 58.338 & 3.219 \\
\hline 5 & 1.491 & 4.384 & 62.722 & 1.491 & 4.384 & 62.722 & 2.513 \\
\hline 6 & 1.319 & 3.879 & 66.601 & 1.319 & 3.879 & 66.601 & 2.363 \\
\hline
\end{tabular}

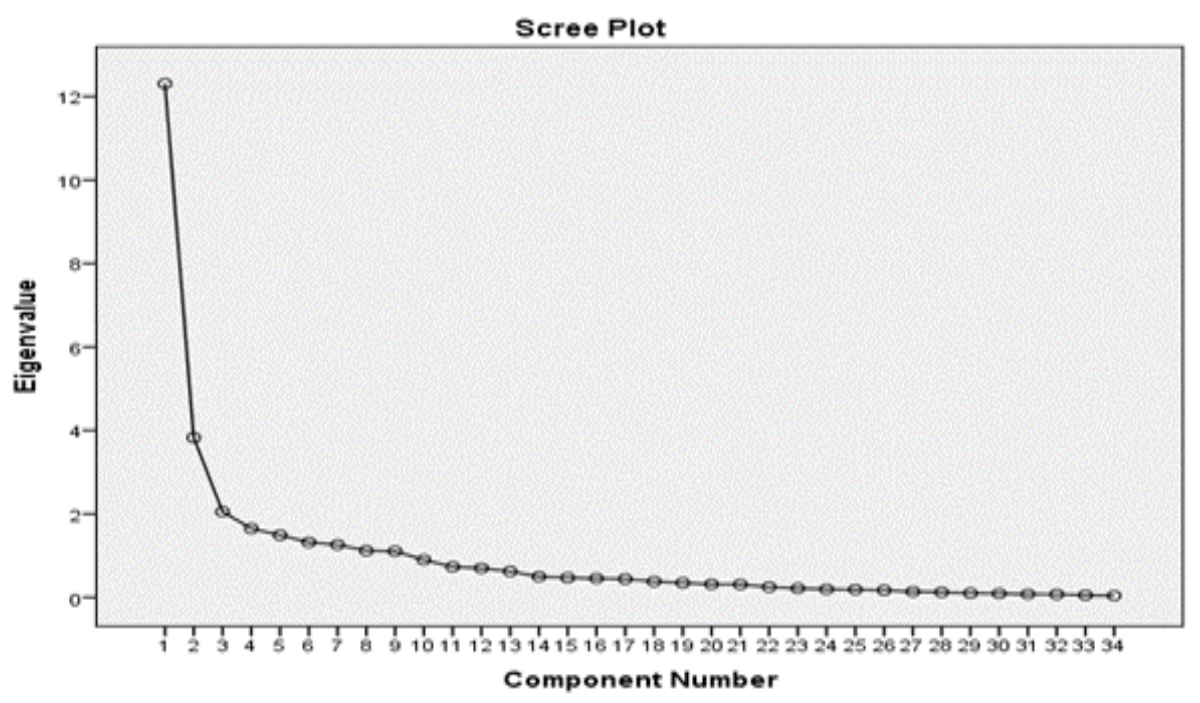

Fig. 1. The scale of scree plot

When Table 2 and Figure 1 are examined, it can be seen that the scale consists of a 6 -factor structure. The 6-factor structure of the scale accounts for $66.60 \%$ of the total variance. These results show that the Student Opinion Scale Related to Moodle LMS (Learning Management System) In an Educational Online Learning Environment is a good indicator of student opinions. 
Paper-Student Opinion Scale Related to Moodle LMS in an Online Learning Environment: Validity ...

Table 3. Scale Items with Factors Mean and Standard Deviation Values

\begin{tabular}{|c|c|c|c|}
\hline Items and Factors & $\begin{array}{l}\text { Rotated } \\
\text { Factor Load } \\
\text { Values }\end{array}$ & $\bar{X}$ & SD \\
\hline Dimension I: Proficiency and Motivation & & 3.95 & .790 \\
\hline I enjoy using Moodle LMS & .810 & 3.96 & .742 \\
\hline $\begin{array}{l}\text { My motivation towards learning Basic Mathematics lessons in the online } \\
\text { environment with Moodle LMS is increased }\end{array}$ & .762 & 4.02 & .747 \\
\hline $\begin{array}{l}\text { I think that I have enough knowledge about Moodle LMS during the Basic } \\
\text { Mathematics education given in the online environment }\end{array}$ & .729 & 4.01 & .775 \\
\hline $\begin{array}{l}\text { I would like to take all the lessons given in the online environment via } \\
\text { Moodle LMS }\end{array}$ & .708 & 3.90 & .934 \\
\hline $\begin{array}{l}\text { With Moodle LMS, learning in online (online) environments, time and } \\
\text { space independent, encourages me to work at my own pace }\end{array}$ & .702 & 4.07 & .790 \\
\hline Using Moodle LMS increases self-confidence & .671 & 3.98 & .677 \\
\hline $\begin{array}{l}\text { I would like to take the Basic Mathematics lesson given in the online envi- } \\
\text { ronment via Moodle LMS }\end{array}$ & .589 & 3.84 & .857 \\
\hline $\begin{array}{l}\text { If I am hesitant to ask questions in the normal classroom, the online envi- } \\
\text { ronment with Moodle LMS encourages me to ask such questions }\end{array}$ & .579 & 3.85 & .784 \\
\hline $\begin{array}{l}\text { The learning activities in Moodle LMS within the Basic Mathematics course } \\
\text { motivate me to succeed }\end{array}$ & .552 & 3.99 & .807 \\
\hline Dimension II: Content and Feedback & & 4.19 & .731 \\
\hline $\begin{array}{l}\text { Real life examples in videos prepared with Moodle LMS for the Basic } \\
\text { Mathematics lesson in the online environment enable a better understanding } \\
\text { of the subjects }\end{array}$ & .724 & 4.32 & .700 \\
\hline $\begin{array}{l}\text { I can get enough feedback from the instructors regarding the questions in } \\
\text { the course by taking advantage of the BigBlueButton platform }\end{array}$ & .718 & 4.13 & .730 \\
\hline I like the Basic Mathematics course design on the Moodle LMS page & .672 & 4.22 & .680 \\
\hline $\begin{array}{l}\text { The calendar-process covered by the Moodle LMS productivity tools can be } \\
\text { used effectively during the learning-teaching process }\end{array}$ & .641 & 4.14 & .808 \\
\hline $\begin{array}{l}\text { I think that the content in the videos prepared for the Basic Mathematics } \\
\text { lesson in the online environment with Moodle LMS is consistent with the } \\
\text { goals related to the subject matter }\end{array}$ & .639 & 4.02 & .856 \\
\hline Visual items used in Moodle LMS increase interest in the lesson & .615 & 4.22 & .680 \\
\hline $\begin{array}{l}\text { With Moodle LMS, I can find the correct and actual content in videos } \\
\text { prepared for Basic Mathematics lessons in online environments }\end{array}$ & .612 & 4.16 & .704 \\
\hline $\begin{array}{l}\text { I think that the topics are better understood by using written documents } \\
\text { directed to the Basic Mathematics course in the online environment via } \\
\text { Moodle IMS }\end{array}$ & .493 & 4.35 & .697 \\
\hline Dimension III: Usability & & 4.09 & .858 \\
\hline The Moodle LMS page is fast & .850 & 4.28 & .914 \\
\hline The links on the Moodle LMS page connect quickly & .728 & 4.24 & .828 \\
\hline I do not have difficulties when using Moodle LMS & .664 & 4.22 & .688 \\
\hline The Moodle LMS page is secure & .637 & 3.92 & .880 \\
\hline The use of Moodle LMS is effective and interesting & .628 & 3.99 & .842 \\
\hline $\begin{array}{l}\text { Through Moodle IMS, I think that the topics are being understood more } \\
\text { effectively by using videos for Basic Mathematics lesson in online (online) } \\
\text { environments }\end{array}$ & .508 & 3.97 & .964 \\
\hline
\end{tabular}




\begin{tabular}{|c|c|c|c|}
\hline $\begin{array}{l}\text { By using Moodle LMS, I can easily access Basic Mathematics course } \\
\text { presentation materials in the online environment }\end{array}$ & .452 & 4.07 & .896 \\
\hline Dimension IV: Effectiveness & & 4.09 & .797 \\
\hline $\begin{array}{l}\text { The Moodle LMS can be effectively utilized during the learning-teaching } \\
\text { process by using the search option within the productivity tools }\end{array}$ & .751 & 4.15 & .831 \\
\hline $\begin{array}{l}\text { The Moodle LMS can be effectively utilized during the learning-teaching } \\
\text { process study offline through the productivity tools }\end{array}$ & .624 & 4.11 & .738 \\
\hline $\begin{array}{l}\text { The Moodle LMS can be effectively utilized during the learning-teaching } \\
\text { process by using the help menu within the productivity tools }\end{array}$ & .559 & 4.11 & .785 \\
\hline $\begin{array}{l}\text { I think that distance education with Moodle LMS is more effective than } \\
\text { traditional classroom teaching }\end{array}$ & .540 & 4.02 & .834 \\
\hline Dimension V: Educational Features & & 4.20 & .736 \\
\hline $\begin{array}{l}\text { Using Moodle LMS, I can easily access Basic Mathematics course content } \\
\text { in the online environment }\end{array}$ & .631 & 4.22 & .656 \\
\hline $\begin{array}{l}\text { With Moodle LMS in the online environment, I can share with the lecturers } \\
\text { and group members by taking advantage of the online forum }\end{array}$ & .556 & 4.17 & .890 \\
\hline $\begin{array}{l}\text { With Moodle LMS, I would like to learn more about online education in the } \\
\text { classroom environment }\end{array}$ & .555 & 4.23 & .662 \\
\hline Dimension VI: Communication & & 4.07 & .783 \\
\hline I can easily communicate with the group members using the online forum & .649 & 3.85 & .926 \\
\hline $\begin{array}{l}\text { I can express my ideas clearly with the instructors and other members in the } \\
\text { online forum }\end{array}$ & .599 & 4.14 & .733 \\
\hline $\begin{array}{l}\text { As a student, I think that I can communicate effectively with Moodle LMS } \\
\text { in the online environment }\end{array}$ & .580 & 4.22 & .691 \\
\hline General Average & & 4.09 & .782 \\
\hline
\end{tabular}

The scale items, rotated factor load values, mean and standard deviation values are given in Table 3. As can be seen in this table, the total item correlations calculated for the 34 items and 6 factors are between .452 and .850 . Moreover, when Table 3 is examined, it is found that the average for all expressions changed between 4.35 and 3.84. It is understood that the responses of the students are generally at the "I agree" level because the general average of all items for the scale of Student Opinion Related to Moodle LMS (Learning Management System) In an Educational Online Learning Environment is 4.09. In this case, it can be said that the opinions of the students about the Moodle LMS (Learning Management System), which is an Educational Online Learning Environment, are good.

When the above table is examined and general averages are taken into account, it can be said that Student Opinions on Moodle LMS with an Educational Online Learning Environment are generally positive.

\section{Discussion and Comments}

In this study, when the general average of all dimensions of students using Moodle LMS Opinions on Moodle LMS with an Educational Online Learning Environment were examined, they were found to be generally positive. This result provides evi- 
dence of the effectiveness of Moodle LMS and its positive contribution to student achievement.

When the studies in the literature are examined. Cavus and Kanbul (2014) conducted a study in order to determine the opinions of students using the open source Moodle (Learning Management System). At the end of the research, it was found that students learned independent of time and place by using Moodle, and their opinions were that the distance learning courses should be based on Moodle.

\section{$5.1 \quad$ Results}

Based on the overall results of the research, it is revealed that student opinions on the online learning environment Moodle LMS are positive. Students participating in the study agreed that the use of Moodle LMS positively affects academic achievement. In addition, students expressed positive opinions in relation to using Moodle in other subjects besides the related course (Basic Mathematics I). It is believed by researchers that Moodle responds to many needs in online teaching and that the ease of use by all users (students, teachers / teaching staff) in online course / course management systems has a positive impact on educational outcomes.

\subsection{Recommendations}

The results of the research show that student opinions on Moodle LMS, an educational online learning environment, are positive. In addition to this, the effectiveness of Moodle LMS in the course and the positive contributions to student achievement have been supported. In this context, it is recommended that Moodle LMS is used in the learning of other course content in addition to the related course. Furthermore, it is recommended for use in other studies as a learning environment evaluation form as the related scale has been shown to be valid and reliable.

\section{Acknowledgment}

We would like to thanks the Near East University Health Services Vocational High School, its students and lecturers, who contributed to the realization of this research.

\section{$7 \quad$ References}

[1] Aydın, C., Ç. \& Biroğul, S. (2008). E-öğrenmede açık kaynak kodlu öğretim yönetim sistemleri ve Moodle. Bilişim Teknolojileri Dergisi, 1(2), 31-36.

[2] Büyüköztürk, Ş. (2013). Sosyal bilimler için veri analizi el kitabı, 14th edn. Pegem Yayınevi, Ankara.

[3] Caputi, V. \& Garrido, A. (2015). Student-oriented planning of e-learning contents for Moodle. Journal of Network and Computer Applications, 53, 115-127. https://doi.org/10.1016/j.jnca.2015.04.001 
Paper-Student Opinion Scale Related to Moodle LMS in an Online Learning Environment: Validity ...

[4] Cavus, N. \& Kanbul, S. (2014). Öğrencilerin öğretim yönetim sistemine yönelik görüşlerinin değerlendirilmesi: Moodle örneği. $8^{\text {th }}$ International Computer \& Instructional Technologies Symposium. Trakya University.

[5] Downes, S. (2006). Learning networks and connective knowledge. Retrieved December 29, 2017, from http://it.coe.uga.edu/itforum/paper92/paper92.html.

[6] Fraenkel, J.R., Wallen, N., E. (2006). How to design and evaluate research in education. McGraw-Hill, New York.

[7] Gürbüztürk, O., Şad, S., N. (2010). Turkish parental involvement scale: validity and reliability studies. Proc-Soc. Behav. Sci. 2(2), 487-491. https://doi.org/10.1016/j.sb spro.2010.03.049

[8] Huang, H. (2002). Toward constructivism for adult learners in online learning environments. British Journal of Educational Technology, 33 (1), 27-37. https://doi.org/10.1111/1467-8535.00236

[9] Hutcheson, G., D. \& Sofroniou, N. (1999). The multivariate social scientist: introductory statistics using generalized linear models. SAGE Publications Limited. https://doi.org/10.4135/9780857028075

[10] Ippakayala, V., K. \& El-Ocla, H. (2017). OLMS: Online learning management system for e-learning. World Journal Educational Technology, Volume: 9, Issue 3, 130-138. https://doi.org/10.18844/wjet.v6i3.1973

[11] Johnson, B., McCLURE, R. (2004). Validity and reliability of a shortened, revised version of the constructivist learning environment survey (CLES). Learn. Environ. Res. 7(1), 6580. https://doi.org/10.1023/B:LERI.0000022279.89075.9f

[12] Morgado, F. F., Meireles, J. F., Neves, C. M., Amaral, A. C., \& Ferreira, M. E. (2017). Scale development: Ten main limitations and recommendations to improve future research practices. Psicologia: Reflexaoe Crítica/Psychology: Research and Review, 30 (3).

[13] Modular Object-Oriented Dynamic Learning Environment (Moodle). Retrieved January 01, 2018, from https://www.techopedia.com/definition/5375/modular-object-orienteddynamic-learning-environment-moodle.

[14] Oproiu, G., C. (2015). A study about using e-learning platform (Moodle) in university teaching process. Procedia-Social and Behavioral Sciences, 180, 426- 432. https://doi.org/10.1016/j.sbspro.2015.02.140

[15] Önal, A., Kaya, A., \& Draman, S., E. (2006). Açık kaynak kodlu çevrimiçi eğitim yazılımları. Akademik Bilişim 2006 (s. 251-254). Denizli: Pamukkale Üniversitesi.

[16] Rice,W. (2006). Moodle E-Learning Course Development, Pakt Publishing.

[17] Sekaran, U. (2003). Research methods for business: a skill-building approach. $4^{\text {th }}$ Edition, John Wiley \& Sons, New York.

[18] Senemoğlu, N. (2011). Gelişim, Öğrenme ve Öğretim. PegemA Yayıncılık. 2. Baskı, Ankara.

[19] Şahinoğlu, E. (2012). Moodle ders yönetimi bilgi sistemi destekli matematik öğretiminin, öğrencilerin matematik başarısına ve matematik dersine yönelik tutumlarına etkisi. Gazi Üniversitesi Eğitim Bilimleri Enstitüsü, Eğitim Bilimleri Anabilim Dalı, Eğitim Teknolojisi Bilim Dalı, Ankara.

[20] Şimşek, Ö. (2015). Moodle 2 ile E-Öğrenme Ders Tasarımı. Pegem Yayınları, Ankara.

[21] Uzunboylu, H., Ozdamli, F. \& Ozcinar, Z. (2006). An evaluation of open source learning management systems according to learners tools. ERIC Document Reproduction Service No. ED494265.

[22] Tsai, C. C. \&Liu, S. Y. (2005). Developing a multi-dimensional instrument for assessing students' epistemological views toward science. International Journal of Science Education, 27(13), 1621-1638. https://doi.org/10.1080/09500690500206432 
Paper-Student Opinion Scale Related to Moodle LMS in an Online Learning Environment: Validity ...

[23] Tuan, H., L., Chang, H., P., Wang, K., H. \& Treagust, D., F. (2000). The development of an instrument for assessing students' perceptions of teacher' knowledge. International Journal of Science Education, 22 (4) : 385-398. https://doi.org/10.1080/095006900289804

[24] Tuluk, A. ve Seferoğlu, S. S. (2016). Açık kaynak kodlu öğrenme yönetim sistemleri: karşılaştırmalı bir inceleme. 2. Uluslararası Eğitim Teknolojisinde Yeni Eğilimler Konferans1 [2 $2^{\text {nd }}$ International Conference on New Trends in Educational Technology] (INTET'2016). 03-04 Mayıs 2016, Gazimağusa, KKTC.

[25] Van Raaij, E. M., \& Schepers, J.,J.,L. (2008). The acceptance and use of a virtual learning environment in China. Computers \& Education, 50(3), 838-852. https://doi.org/10.1016/ j.compedu.2006.09.001

\section{Authors}

Ezgi Pelin Yildiz is with the Department of Computer Education Information Technology, Near East University, Nicosia, Cyprus.

Murat Tezer is with the Department of Mathematics Education, Near East University, Nicosia, Cyprus.

Hüseyin Uzunboylu is with the Department of Education Science, Near East University, Nicosia, Cyprus.

Article submitted 01 July 2018. Resubmitted 23 July 2018. Final acceptance 03 August 2018. Final version published as submitted by the authors. 